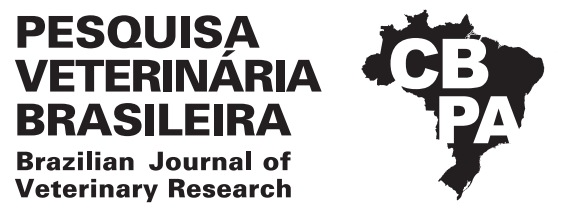

Pesq. Vet. Bras. 38(11):2037-2043, novembro 2018 DOI: 10.1590/1678-5150-PVB-5867

Original Article

Animais de Produção/Livestock Diseases

ISSN 0100-736X (Print)

ISSN 1678-5150 (Online)

\title{
Survey of Salmonella spp. in beef meat for export at slaughterhouses in Brazil ${ }^{1}$
}

\author{
Daniele Bier², Jalusa D. Kich", Sabrina C. Duarte ${ }^{4}$, Márcio R. Silva ${ }^{5}$, \\ Luiza M. Valsoni ${ }^{2}$, Carlos A.N. Ramos ${ }^{6}$, Dália P. Rodrigues ${ }^{7}$ and Flábio R. Araújo ${ }^{3 *}$
}

\begin{abstract}
Bier D., Kich J.D., Duarte S.C., Silva M.R., Valsoni L.M., Ramos C.A.N., Rodrigues D.P. \& Araújo F.R. 2018. Survey of Salmonella spp. in beef meat for export at slaughterhouses in Brazil. Pesquisa Veterinária Brasileira 38(11):2037-2043. Setor de Sanidade Animal, Embrapa Gado de Corte, Av. Rádio Maia 830, Zona Rural, Campo Grande, MS 79106-550, Brazil. E-mail: flabio.araujo@embrapa.br

The aim of the present study was to investigate the presence of Salmonella spp. in samples collected from beef meat at three points of the slaughter line (after skinning, washing and cooling) at three slaughterhouses in Brazil that export meat. Detection was based on ISO 6579:2002 and confirmed by PCR and qPCR. The isolates were typified using slide agglutination tests and PFGE. The antibiotic sensitivity profile was determined using the disk diffusion method. Contamination was detected in only one slaughterhouse. The overall frequency of contamination by Salmonella spp. was $6.7 \%$ of carcasses $(6 / 90)$ and $2.6 \%$ of carcass surface samples $(7 / 270)$. All isolates were confirmed by PCR and qPCR. The serological analysis and the PFGE showed a single profile: Typhimurium. The strains demonstrated $100 \%$ susceptibility to ampicillin, cefotaxime, ciprofloxacin, chloramphenicol, gentamicin and tetracycline. Positive carcasses after cooling pose a direct risk to consumers, since the meat is considered ready to be marketed after this process.
\end{abstract}

INDEX TERMS: Salmonella spp., beef meat, slaughterhouses, Brazil, serotype, antibiotic resistance, salmonellosis, skinning, cooling, carcass, cattle.

RESUMO.- [Pesquisa de Salmonella spp. em carcaças bovinas durante o processamento em abatedouros-frigoríficos exportadores.] 0 objetivo deste trabalho foi investigar a presença de Salmonella spp. em amostras coletadas de carcaças de bovinos, em três pontos da linha de abate (após a esfola, lavagem e refrigeração) de três frigoríficos exportadores no Brasil. A detecção foi realizada pela ISO 6579:2002, e

\footnotetext{
${ }^{1}$ Received on September 3, 2018.

Accepted for publication on September 12, 2018.

${ }^{2}$ Curso de Medicina Veterinária, Universidade Católica Dom Bosco (UCDB), Av. Tamandaré 6000, Jardim Seminário, Campo Grande, MS 79117-900, Brazil.

${ }^{3}$ Grupo de Produção Animal, Embrapa Gado de Corte, Av. Rádio Maia 830, Zona Rural, Campo Grande, MS 79106-550. *Corresponding author: flabio.araujo@embrapa.br

${ }^{4}$ Núcleo Temático de Sanidade de Suínos, Embrapa Suínos e Aves, Rodovia BR-153 Km 110, Concórdia, SC 89715-899, Brazil.

${ }^{5}$ Setor de Saúde Animal e Qualidade do Leite, Embrapa Gado de Leite, Eugênio do Nascimento 610, Juiz de Fora, MG 36038-330, Brazil.

${ }^{6}$ Faculdade de Medicina Veterinária e Zootecnia (FAMEZ), Universidade Federal de Mato Grosso do Sul (UFMS), Av. Senador Felinto Muller 2443, Pioneiros, Campo Grande, MS 79070-900.

${ }^{7}$ Laboratório de Enterobactérias, Instituto Oswaldo Cruz, Av. Brasil 4365, Rio de Janeiro, RJ 21040-900, Brazil.
}

confirmada por PCR e qPCR. Os isolados foram tipificados por testes de soroaglutinação e PFGE e avaliado o perfil de sensibilidade aos antibióticos pelo método de difusão em disco. A contaminação foi detectada em apenas um abatedouro-frigorífico. As contaminações das carcaças ( $\mathrm{n}=90$ ) e amostras de carne $(\mathrm{n}=270)$ por Salmonella spp. foram $6(6,7 \%)$ e $7(2,6 \%)$, respectivamente. Todos os isolados foram confirmados por PCR e qPCR. A análise sorológica e o PFGE mostraram um único perfil: Typhimurium. As cepas apresentaram $100 \%$ de suscetibilidade à ampicilina, cefotaxima, ciprofloxacina, cloranfenicol, gentamicina e tetraciclina. As carcaças positivas após a refrigeração apresentam um risco direto para o consumidor, uma vez que, após este processo, a carne está pronta para ser comercializada.

TERMOS DE INDEXAÇÃO: Salmonella spp., carcaças bovinas, abatedouros-frigoríficos, sorotipo, resistência a antibióticos, salmonelose, carne bovina, esfola, resfriamento, bovinos.

\section{INTRODUCTION}

Beef is one of the most important foods in the human diet and has a considerable impact on the economies of different countries (Sans \& Combris 2015). Brazil has been the largest 
exporter of beef in the world since 2008, and reached an export volume has reached 1.6 million tons, with gross revenues of approximately US $\$ 7.1$ billion, which represents $28 \%$ of the international trade (Brasil 2015). Brazil exports to more than 170 countries in various regions of the world, such as Latin America, Middle East, Russia, the European Union and Africa (ABIEC 2016).

The state of Mato Grosso do Sul in the central western region of the country is the fourth largest cattle producer in Brazil and second in the number of slaughtered cattle, with an annual harvest of 3.9 million heads of cattle and an accumulated carcass weight of 849,000 tons (IAGRO 2018). With regard to beef exports, Mato Grosso do Sul represents 9.4\% of the country's total, exporting mainly to Hong Kong, China, Egypt, Russia, Iran, Venezuela, Chile, Italy, Vietnam and the Netherlands (Brasil 2016).

Despite being one of the most important items in the human diet and an industry with considerable potential for growth, meat and meat products are considered one of the main vehicles of pathogens to humans (Rhoades et al. 2009), causing foodborne illnesses. Microbiological contamination of cattle carcasses occurs mainly during processing and handling, such as skinning, gutting, cutting, packaging, storage and distribution (Jay 2000, Borch \& Arinder 2002, Madden et al. 2004). Cross-contamination by pathogenic bacteria through utensils used during the handling of meat is an important factor in the development of foodborne illnesses (Perez-Rodriguez et al. 2010, Papadopoulou et al. 2012). According to the World Health Organization, Salmonella sp. is one of the most relevant pathogens in beef and its presence poses a risk to consumers (WHO 2005). Salmonella ser. Typhimurium has been reported to be the serovar involved foodborne illnesses most frequently associated with the consumption of contaminated poultry, pork and beef (EFSA 2015).

The import market sets standards of quality and hygiene to be achieved by producing countries. In general, meat destined for foreign markets should be analyzed for the presence of pathogenic microorganisms and constraints to the marketing of these products may occur when microbiological criteria set by importing countries are not met (Wilhelm et al. 2011). The Rapid Alert System for Food and Feed (RASFF) of the European Union (EU) was created for the regulation of such products. When a risk to public health is identified, necessary measures are established, such as withholding, notification, seizure or rejection of these dangerous products. Through this warning system, health authorities in the EU have confiscated shipments of meat from Brazil, Argentina, Australia and the United States as the result of stiff control measures directed at pathogens, such as Salmonella, which has led to a degree of uncertainty among exporters and importers. From February 2016 to February 2018, two shipments of Brazilian beef were confiscated and notifications were issued regarding the presence of Salmonella spp. (RASFF 2018).

The United States requires daily testing for Escherichia coli and Salmonella spp., while the EU requires the enumeration of aerobic mesophilic microorganisms and enterobacteria in addition to the detection of Salmonella spp. (Commission Regulation-EC 2007). According to current microbiological standards of the Brazilian Health Regulatory Agency, chilled or frozen carcasses must be free of Salmonella spp. (Brasil 2001).
Quantitative and qualitative studies on microbiological safety are very important to the production of high quality meat products. The identification of potentially pathogenic microorganisms, such as Salmonella, in beef meat during slaughter operations contributes significantly to the implementation of quality monitoring programs and preventive measures, consequently reducing the risks to public health (Martínez-Chávez et al. 2015).

The aim of the present study was to investigate the presence of Salmonella spp. in cattle carcasses at different points in the slaughtering process at slaughterhouses in the state of Mato Grosso do Sul, Brazil, that produce beef for export. For such, different diagnostic methods were employed and the antibiotic sensitivity of the isolated strains was determined.

\section{MATERIALS AND METHODS}

Samples. Samples from beef meat were collected from three slaughterhouses registered with the Brazilian Federal Inspection Service and located in the state of Mato Grosso do Sul, Brazil.

At each slaughterhouse, samples were taken from five carcasses per week for six consecutive weeks, as established by the EU for microbiological testing on carcasses (Commission Regulation-EC 2007) and stipulated in Circular 463 of the Brazilian International Trade Control Division, Department of Animal Product Inspection, which establishes control programs for slaughterhouses that export to the United States and EU member states (Brasil 2004).

Samples were taken from each animal using a non-destructive method at three different points of the slaughter line: after skinning, after washing and after cooling. Dehydrated, sterilized sponges (Speci-Sponge - Nasco, Fort Atkinson, Wisconsin, USA) measuring $11.5 \times 23.0 \mathrm{~cm}$ and individually packed in sterile plastic bags (Whirl Pak, Nasco, Fort Atkinson, Wisconsin, USA) were used for the collection of the samples. The sponges were hydrated with $10 \mathrm{~mL}$ of $1 \%$ buffered peptone water (1\% BPW) (HiMedia Laboratories, Mumbai, India) and rubbed onto the chest $\left(100 \mathrm{~cm}^{2}\right)$, flank $\left(100 \mathrm{~cm}^{2}\right)$ and rump close the occlusion of the rectum $\left(200 \mathrm{~cm}^{2}\right)$ using a sterile stainless steel mold measuring $10 \times 10 \mathrm{~cm}$ (total sampled surface: $400 \mathrm{~cm}^{2}$ ). The same carcass was tracked through each of the three stations at which samples were collected. The sponges were transferred to the plastic bags (Nasco, Fort Atkinson, Wisconsin, USA) and transported to the laboratory under refrigeration.

Strains from the microorganism reference collection of the Oswaldo Cruz Institute (FIOCRUZ-INCQS), Rio de Janeiro, Brazil, were used as negative and positive controls for all techniques: Escherichia coli INCQS 00033 (ATCC 25922), Citrobacter freundii INCQS 00576 (ATCC 43864), Salmonella enterica subsp. enterica serovar Enteritidis INCQS 00258 (ATCC 13076) and S. enterica subsp. enterica serovar Typhimurium INCQS 00150 (ATCC 14028).

Bacterial isolation. A total of $200 \mathrm{~mL}$ of $1 \%$ BPW were added to each plastic bag containing the sponges. The mixture was homogenized in a stomacher (Lab-blender 400BA 6021, Seward Laboratory, London, England) for $60 \mathrm{sec}$ and placed in Erlenmeyer flasks, which were incubated at $37 \pm 1^{\circ} \mathrm{C}$ for $18 \pm 2 \mathrm{~h}$. Detection of Salmonella spp. was performed according to the method recommended by the International Standardization Organization (ISO 2002), with modifications. After enrichment (with BPW), selection (with Muller-Kauffmann Tetrathionate-Novobiocin Broth and Rappaport-Vassiliadis Soya Peptone Broth) and differentiation (with Xylose-Lysine-Desoxycholate and Salmonella-Shigella agar) steps, suspected colonies isolated from standard cultivation media were subjected to further biochemical tests, which included indole, 
urea, motility, lysine decarboxylation, $\mathrm{H}_{2} \mathrm{~S}$ production, methyl red, Voges-Proskauer, carbohydrate fermentation (Triple Sugar Iron), citrate and $\beta$-galactosidase.

DNA extraction. Prior to DNA extraction, the isolates were incubated in nutrient agar. The extraction of bacterial DNA for polymerase chain reaction (PCR) and real-time polymerase chain reaction (qPCR) analyses was performed using the DNeasy Blood and Tissue kit (QIAGEN, Valencia/CA, USA), following the manufacturer's instructions. The isolates of the following samples were used for DNA extraction:

- Samples biochemically compatible with Salmonella spp.

- Samples with inconclusive biochemical identification for Salmonella spp. (doubtful results for $\beta$-galactosidase and citrate)

- A random sample ( $n=85)$ selected from a total of 259 samples biochemically incompatible with Salmonella spp.

End-point PCR. End-point PCR for the confirmation of Salmonella spp. was performed based on the method described by Myint, et al. (2006) using invA primers (Skyberg et al. 2006) targeting invA gene. Amplicons were separated by $1.5 \%$ agarose gel electrophoresis in TAE buffer with GelRed (Biotium, Hayward/CA, USA). The image was then recorded with the L-PIX Image EX photo documenter (Loccus Biotechnology, Loccus Brazil, Cotia/SP, Brazil).

Real-time PCR. For RT-PCR, primers and DNA probes for the TaqMan MGB system were designed with the Primer Express program (Applied Biosystems, Foster City/CA, USA) targeting invA (Table 1). DNA detection was performed using the StepOne Plus system (Applied Biosystems, Foster City/CA, USA).

Serotyping. The Salmonella spp. isolates identified by biochemical methods, PCR and qPCR were sent to the National Reference Laboratory for Cholera and Bacterial Entero-Infections of the Oswaldo Cruz Institute (Fiocruz), Rio de Janeiro/RJ, Brazil, for serotyping by slide agglutination using the Kauffmann-White scheme with $\mathrm{O}$ and $\mathrm{H}$ antisera.

Pulsed-field gel electrophoresis. The Salmonella spp. isolates identified by biochemichal methods, PCR and qPCR were analyzed using pulsed-field gel electrophoresis (PFGE). The bacterial suspension was embedded in agarose, lysed, washed and digested with the restriction enzyme XbaI (New England Biolabs, Beverly, MA, USA) overnight (12-16h) at $37^{\circ} \mathrm{C}$, essentially as described in the "One-Day (24-28h) Standardized Laboratory Protocol for Molecular Subtyping of Escherichia coli 0157:H7, non-typhoidal Salmonella serotypes, and Shigella sonnei by pulsed field gel electrophoresis (PFGE)" of the Centers for Disease Control and Prevention (Atlanta/GA, USA, http://www.cdc.gov/pulsenet/ protocols.htm) (Ribot et al 2006). Electrophoresis was performed in $1 \%$ agarose gel using $0.5 x$ Tris-borate-EDTA buffer on a Chef Mapper XA (BioRad Laboratories, Hercules/CA) at $6 \mathrm{~V} / \mathrm{cm}$ for $19 \mathrm{~h}$ at $14^{\circ} \mathrm{C}$ with an initial switch time of $2 \mathrm{~min} 16 \mathrm{sec}$ and a final switch

Table 1. Primers and DNA probes for TaqMan MGB system targeting inv $A$

\begin{tabular}{ccc}
\hline $\begin{array}{c}\text { Target } \\
\text { gene }\end{array}$ & Primers and probe $\left(5^{\prime}-3^{\prime}\right)$ & $\begin{array}{c}\text { Expected } \\
\text { amplicon size (bp) }\end{array}$ \\
\hline
\end{tabular}
Forward: GCG AGC AGC CGC TCA GT

invA Reverse: CGA GAT CGC CAA TCA GTC CTA Probe: NED-TGA GGA AAA AGA AGG GTC GT-MGBNFQ time of $63.8 \mathrm{sec}$. Gels were stained for $30 \mathrm{~min}$ at room temperature with ethidium bromide (Invitrogen, Carlsbad/CA), destained and photographed. Salmonella Braenderup (ATCC BAA-664) was included as reference. Pattern images were acquired using a Kodak Gel Logic 2200 system and analyzed using the BioNumerics software program, version 2.0 (Applied Maths BVBA, Sint-Martens-Latem, Belgium). Similarities between isolate fingerprints were determined based on the Dice correlation coefficient (Hunter \& Gaston 1988). A band position tolerance of $1.7 \%$ was used for the analysis of PFGE patterns (Carriço et al. 2005). Dendrograms were generated by unweighted pairwise grouping with mathematical averaging (UPGMA). Isolates were considered as having the same pulsotype when the number and location of the bands were indistinguishable. Isolates with one band difference were considered to be of distinct pulsotypes.

Antimicrobial susceptibility profile. The antimicrobial susceptibility of the Salmonella spp. strain isolates was determined using the disk diffusion method recommended by the Clinical and Laboratory Standards Institute (CLSI 2011), employing the following antibiotics: ampicillin, cefotaxime, ciprofloxacin, chloramphenicol, gentamicin and tetracycline.

Statistical analyses. The rates of positive samples in each evaluation period (after skinning, after washing and after cooling) were compared using the OpenEpi software program (Dean et al. 2013). Fisher's exact test with the mid-p method for matched pairs was used to determine associations between each two evaluation periods and the presence/absence of Salmonella.

\section{RESULTS}

Among the 90 samples from 30 carcasses at Slaughterhouse I, seven $(7.7 \%)$ isolates from six carcasses were biochemically compatible with Salmonella spp.: three carcasses were positive after cooling, two were positive after skinning and after washing and one carcass had two positive samples (after skinning and after cooling). All carcasses analyzed at Slaughterhouses II and III were negative for Salmonella spp. (Table 2).

Fisher's exact with the mid-p method for matched pairs revealed no statistically significant associations ( $p>0.05)$ between each two evaluation periods and the presence/absence of Salmonella spp. However, a tendency toward an increase in differences regarding positivity was found in the comparisons after skinning/after washing, after skinning/after cooling and after washing/after cooling, as demonstrated by the decrease in p-values (Table 3).

Among 270 samples collected from the three slaughterhouses, seven isolates biochemically compatible with Salmonella, four inconclusive isolates and 85 isolates biochemically incompatible with Salmonella were tested using end-point PCR and qPCR. Four samples with inconclusive biochemical profiles and 85 samples biochemically incompatible for Salmonella spp. were all negative in the end-point PCR and qPCR. The seven isolates biochemically compatible with Salmonella spp. were also confirmed by conventional PCR and pPCR and exhibited one profile after serotyping. Table 4 displays the positive carcasses, points of contamination and serotype of Salmonella spp.

These strains of Salmonella spp. were also analyzed by PFGE and exhibited 100\% similarity (Fig.1).

Regarding the sensitivity profile to antimicrobials, the strains of Salmonella spp. isolated from cattle carcasses demonstrated $100 \%$ sensitivity to gentamicin, ampicillin, 
Table 2. Samples from beef meat contaminated with Salmonella spp. after skinning, washing and cooling at three slaughterhouses that export meat, Mato Grosso do Sul, Brazil

\begin{tabular}{|c|c|c|c|c|c|}
\hline Source & Number of carcasses & Positive carcasses & $\begin{array}{c}\text { Positive samples after } \\
\text { skinning (\%) }\end{array}$ & $\begin{array}{l}\text { Positive samples } \\
\text { after washing (\%) }\end{array}$ & $\begin{array}{l}\text { Positive samples } \\
\text { after cooling (\%) }\end{array}$ \\
\hline Slaughterhouse I & 30 & $6(20 \%)$ & $2(6.6 \%)$ & $1(3.3 \%)$ & $4(13.3 \%)$ \\
\hline Slaughterhouse II & 30 & $0(0 \%)$ & $0(0 \%)$ & $0(0 \%)$ & $0(0 \%)$ \\
\hline Slaughterhouse III & 30 & $0(0 \%)$ & $0(0 \%)$ & $0(0 \%)$ & $0(0 \%)$ \\
\hline TOTAL & 90 & $6(6.7 \%)$ & $2(2.2 \%)$ & $1(1.1 \%)$ & $4(4.4 \%)$ \\
\hline
\end{tabular}

Table 3. Comparison of evaluation periods and presence/absence of Salmonella using matched pairs of same carcasses

\begin{tabular}{|c|c|c|c|}
\hline \multicolumn{2}{|c|}{ Pair-matched comparisons } & \multicolumn{2}{|c|}{ p-values (Fisher's exact test - mid-p method) } \\
\hline Pair 1 (\% of positive) & Pair 2 (\% of positive) & 1-tail & 2-tail \\
\hline After skinning (2.2) & After washing (1.1) & 0.3125 & 0.6250 \\
\hline After skinning (2.2) & After cooling (4.4) & 0.1875 & 0.3750 \\
\hline After washing (1.1) & After cooling (4.4) & 0.1094 & 0.2188 \\
\hline
\end{tabular}

Table 4. Serotyping of seven strains of Salmonella spp. isolated from 270 beef samples in three different steps of slaughter line destined for export, Mato Grosso do Sul, Brazil

\begin{tabular}{ccccc}
\hline Sample & Skinning & Washing & Cooling & Serotype \\
\hline Carcass 37 & Negative & Positive & Negative & Typhimurium \\
Carcass 44 & Positive & Negative & Positive & Typhimurium \\
Carcass 48 & Negative & Negative & Positive & Typhimurium \\
Carcass 57 & Negative & Negative & Positive & Typhimurium \\
Carcass 60 & Negative & Negative & Positive & Typhimurium \\
Carcass 64 & Positive & Negative & Negative & Typhimurium
\end{tabular}

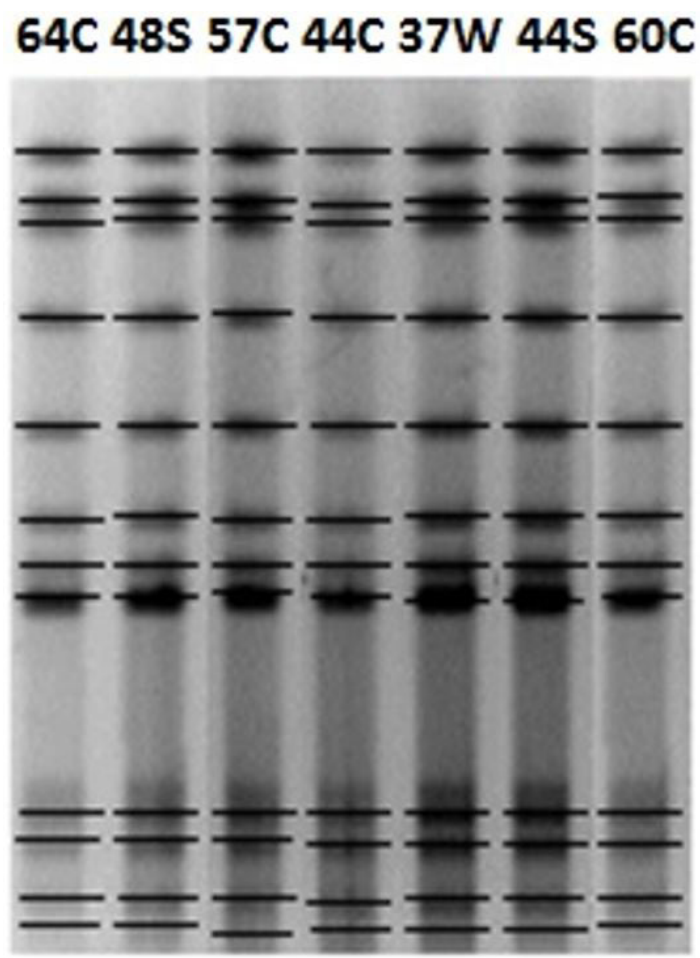

Fig.1. Profile of macrorestriction genomic DNA analysis of Salmonella spp. isolated from 90 bovine carcasses in slaughterhouse that exports meat, Mato Grosso do Sul, Brazil. S = Skinning, $\mathrm{W}=$ washing, $\mathrm{C}=$ cooling. tetracycline, chloramphenicol, ciprofloxacin and cefotaxime (Table 5).

\section{DISCUSSION}

In the present study, seven isolates of Salmonella spp. were recovered from beef meat. Two isolates (2.2\%) were found after skinning, which is a critical point of the slaughtering process due to the possibility of contamination of the substrate surface by microorganisms present on the skin, hair and hooves of the animal (Lambert et al. 1991, Penney et al. 2007). After washing, only one carcass (1.1\%) exhibited Salmonella spp. Indeed, the purpose of this step is to reduce the microbial load in slaughterhouses (Dickson 1988). According to Brazilian legislation, maintenance of a minimum of $0.2 \mathrm{mg} / \mathrm{L}$ and a maximum of $2 \mathrm{mg} / \mathrm{L}$ of free residual chlorine in water is mandatory (Brasil 2011). Surprisingly, however, four isolates $(4.4 \%)$ were found after cooling, which may have been due to contamination during the movement of the carcasses into the cooling chamber. Low temperatures reduce the number of microorganisms, but do not cause complete obliteration (Michener \& Elliott 1964). This contamination may have occurred indirectly through the instruments used for slaughtering, workers' clothes (Prasai et al. 1995, Rahkio \& Korkeala 1996, Pordesimo et al. 2002, Podpečan et al. 2007) and the hands of meat handlers (Bell 1997, Gill \& McGinnis 2003). The floor can also be an important source of contamination through the transfer of organic matter to the shoes of workers or the spreading of microorganisms by cleaning with water under high pressure (Barros et al. 2007).

Positive carcasses for Salmonella after cooling pose a direct risk to consumers, since the meat is considered ready to be marketed after this process. It is well established that a high percentage of foodborne illnesses are caused by the failure of consumers to prepare food in a hygienic manner. Indeed, a common practice in households is to use the same kitchen equipment for both raw meat and fresh raw salads and fruits. Such a practice may lead to the cross-contamination of pathogenic microorganisms from raw meat to fruits and vegetables, which are mainly consumed without further processing. More seriously, washing or disinfecting kitchen equipment may not be sufficient to avoid the cross-contamination 
Table 5. Sensitivity to antimicrobials of Salmonella strains isolated from bovine carcasses at slaughterhouse that exports meat, Mato Grosso do Sul, Brazil

\begin{tabular}{|c|c|c|c|c|c|c|}
\hline Strain & Ampicillin & Gentamicin & Ciprofloxacin & Cefotaxime & Chloramphenicol & Tetracycline \\
\hline $37 \mathrm{~W}$ & $S$ & $S$ & $S$ & $S$ & $S$ & S \\
\hline $44 \mathrm{~S}$ & S & S & S & S & S & S \\
\hline $44 \mathrm{C}$ & S & $S$ & S & S & S & S \\
\hline $57 \mathrm{C}$ & S & $S$ & $S$ & $S$ & S & S \\
\hline $60 \mathrm{C}$ & $\mathrm{S}$ & S & S & S & S & S \\
\hline
\end{tabular}

$\overline{\mathrm{S}}=$ Skinning, $\mathrm{W}=$ Washing, $\mathrm{C}=$ Cooling; $\mathrm{S}=$ sensitive, $\mathrm{I}=$ intermediate, $\mathrm{R}=$ resistant; ${ }^{1}$ S. Typhimurium INCQS 00150 (ATCC 14028).

of $S$. enterica Serovar Typhimurium to ready-to-eat foods (Gkana et al. 2016).

Among the seven strains serotyped in the present study, all were Typhimurium and exhibited a single pattern in PFGE. This result demonstrates a clonal relationship among these strains, indicating the presence of the same serovar, Typhimurium, probably from a same clone, and suggesting local contamination restricted to the slaughter room or a handler.

In the present investigation, some strains exhibited an inconclusive biochemical pattern for Salmonella spp. after culturing, pre-enrichment, selective enrichment differential plating and biochemical methods and were confirmed negative for Salmonella by the molecular tests. Biochemical tests identify Salmonella by the phenotypic profile, which, however, can exhibit variability due to the effect of environmental factors on gene expression and may lead to false-negative reactions or misinterpretations (Farber et al. 2001, Malorny et al. 2003, Settanni \& Corsetti 2007).

Due to the short life of meat products, faster diagnostic methods are needed. There is considerable discussion about the applicability of PCR for the direct detection of Salmonella in meat products or carcasses, since the technique detects all viable, injured and dead bacteria (Malorny et al. 2003, Ibrahim et al. 2014) and the results may therefore not be valid, as injured or dead bacteria would not cause infection in the host. Thus, complementary diagnostic methods are often required, considering the possibility of false negatives due to inhibitory substances as well as false positives due to the detection of injured or dead bacteria (Wilson 1997). However, PCR from the isolates of Salmonella minimizes this error and increases the sensitivity of the technique, with the association of two or more enrichment broths with plating media resulting in a greater number of isolates of Salmonella (Busse 1995, Rall et al. 2005). Furthermore, PCR with isolates on selective plating saves two days in comparison to the traditional culture method as well as minimizes the labor expended and the possible misinterpretation of biochemical tests.

The increase in multi-antimicrobial-resistant Salmonella strains isolated from humans has been associated with the widespread use of antimicrobial agents in food animal production (Brown et al. 2017). The spread of antimicrobial resistance through the food chain is regarded as a major public health issue (Raufu et al. 2014). Thus, the analysis of antimicrobial susceptibility is crucial in the clinical and epidemiological context (Silley 2012). The antimicrobial sensitivity profile allows tracing the spread of multidrug-resistant strains
(Olsen et al. 1993, Oueslati et al. 2016). In the case of Salmonella, Hur et al. (2012) reported an increase in Typhimurium and Newport multidrug-resistant serotypes. The multidrug-resistant S. enterica serovar Typhimurium definitive phage type harbors a chromosomally encoded genomic island (Salmonella Genomic Island 1), which is typically responsible for resistance to ampicillin, chloramphenicol, streptomycin, sulfonamide and tetracycline (Hur et al. 2012) and has been isolated from human and pork samples, suggesting the transfer of resistance to humans via meat consumption (Van Boxstael et al. 2012). The strains of S. enterica serovar Typhimurium isolated in the present study demonstrated $100 \%$ susceptibility to ampicillin, chloramphenicol and tetracycline, suggesting that these isolates do not harbor the penta-resistant genomic island.

The prevalence of Salmonella spp. in beef is quite variable and depends on many factors, such as weather conditions, type of management, slaughter conditions and the storage and transportation of carcasses. Cross-contamination and incorrect handling practices are often associated with the contamination of beef, making it particularly difficult to identify the primary source of contamination (Perez-Rodriguez et al. 2010).

\section{CONCLUSIONS}

Salmonella spp. was found in beef meat at only one of the slaughterhouses investigated and the frequency was low.

The occurrence of bovine carcasses contaminated with Salmonella spp. after cooling imposes a direct risk to consumers, since the meat is considered ready to be marketed after this process.

Acknowledgments.- The authors are grateful to the Brazilian fostering agency Fundação de Apoio ao Desenvolvimento do Ensino, Ciência e Tecnologia do Estado de Mato Grosso do Sul, Fundect (grant number: 23/200.479/2014), Universidade Católica Dom Bosco and Embrapa Gado de Corte (grant numbers: 03.14.00.047.00.00 and 03.13.10.008.00.00).

\section{REFERENCES}

ABIEC 2016. Exportações Brasileiras de Carne Bovina, janeiro a dezembro de 2015. Associação Brasileira das Indústrias Exportadoras de Carne. Available at <http://www.abiec.com.br/download/relatorio-anual-2015. pdf $>$ Accessed on Nov. 5, 2016.

Barros M.F.A., Nero L.A., Monteiro A.A. \& Beloti V. 2007. Identification of main contamination points by hygiene indicator microorganisms in beef processing plants. Food Sci. Technol. 27(4):856-862. <http://dx.doi org/10.1590/S0101-20612007000400028> 
Bell R.G. 1997. Distribution and sources of microbial contamination on beef carcasses. J. Appl. Microbiol. 82(3):292-300. <http://dx.doi. org/10.1046/j.1365-2672.1997.00356.x><PMid:12455892>

Borch E. \& Arinder P. 2002. Bacteriological safety issues in red meat and readytreat meat products, as well as control measures. Meat Sci. 62(3):381-390. <http://dx.doi.org/10.1016/S0309-1740(02)00125-0><PMid:22061614>

Brasil 2001. Resolução RDC 12 de 2 de janeiro de 2001. Regulamento Teórico Sobre Padrões Microbiológicos Para Alimentos no 7-E, Agência Nacional de Vigilância Sanitária (ANVISA), Diário Oficial da República Federativa do Brasil, Brasil, p.46-53.

Brasil 2004. Programas de autocontroles de estabelecimento produtor de carne bovina habilitados para os Estados Unidos (EUA) e para EstadosMembros da União Europeia (UE). Circular №463/DCI/DIPOA/2004, Divisão de Controle do Comercio Internacional (DCI), Departamento de Inspeção de Produtos de Origem Animal (DIPOA), Secretaria de Defesa Agropecuária (DAS), Ministério da Agricultura, Pecuária e Abastecimento.

Brasil 2011. Dispõe sobre os procedimentos de controle e de vigilância da qualidade da água para consumo humano e seu padrão de potabilidade. Portaria no 2914 de 12 de dezembro de 2011, Diário Oficial da República Federativa do Brasil, Ministério da Saúde, Brasília. Brazil 2015. Resultados de 2015, perspectivas para 2016. Estatísticas de Comercio Exterior do Agronegócio Brasileiro (Agrostat), Secretaria de Relações Internacionais do Agronegócio (SRI), Ministério da Agricultura, Pecuária e Abastecimento. Available at <http://www.agricultura.gov.br/arq_editor/file/acs/ apresentacao1.pdf> Accessed on Jun. 1, 2016.

Brasil 2015. Resultados de 2015, perspectivas para 2016. Estatísticas de Comércio Exterior do Agronegócio Brasileiro (Agrostat), Secretaria de Relações Internacionais do Agronegócio (SRI), Ministério da Agricultura, Pecuária e Abastecimento. Available at <http://www.agricultura.gov.br/ arq_editor/file/acs/apresentacao1.pdf> Accessed on Sep. 6, 2016.

Brasil 2016. Estatística da produção pecuária, março de 2016. Indicadores IBGE, Comissão Especial de Planejamento, Controle e Avaliação das Estatísticas Agropecuárias, (Cepagro), Instituto Brasileiro de Geografia e Estatística. Available at <http://www.ibge.gov.br/home/estatistica/ indicadores/agropecuaria/producaoagropecuaria/abate-leite-couroovos_201504_publ_completa.pdf> Accessed on Jun. 1, 2016.

Brown A.C., Grass J.E., Richardson L.C., Nisler A.L., Bicknese A.S. \& Gould L.H. 2017. Antimicrobial resistance in Salmonella that caused foodborne disease outbreaks: United States, 2003-2012. Epidemiol. Infect. 145(4):766-774. <http://dx.doi.org/10.1017/S0950268816002867> <PMid:27919296>

Busse M. 1995. Media for Salmonella. Int. J. Food Microbiol. 26(1):117-131. <http://dx.doi.org/10.1016/0168-1605(93)E0030-U><PMid:7662516>

Carriço J.A., Pinto F.R., Simas C., Nunes S., Sousa N.G., Franzão N., de Lencastre H. \& Almeida J.S. 2005. Assessment of band-based similarity coefficients for automatic type and subtype classification of microbial isolates analyzed by pulsed-field gel electrophoresis. J Clin. Microbiol. 43(11):5483-5490. <http://dx.doi.org/10.1128/JCM.43.11.5483-5490.2005><PMid:16272474>

CLSI 2011. Twenty-first informational supplement Performance Standards for Antimicrobial Susceptibility Testing, Vol.1, Clinical and Laboratory Standards Institute.

Commission Regulation-EC 2007. Microbiological criteria for foodstuffs. European Commission $N^{\circ} 1441 / 2007$ (ameding Regulation $N^{\circ} 2073 / 2005$ ). Oficial Journal of the European Union L322:12-29.

Dean A.G., Sullivan K.M. \& Soe M.M. 2013. OpenEpi: open source epidemiologic statistics for public health. Available at <www.OpenEpi.com> Accessed on Jul. 21, 2016.

Dickson J.S. 1988. Reduction of bacteria attached to meat surfaces by washing with selected compounds. J. Food Protect. 51(11):869-873. <http://dx.doi. org/10.4315/0362-028X-51.11.869>

EFSA. 2015. EU summary report on antimicrobial resistance in zoonotic and indicator bacteria from humans, animals and food in 2013. European Food Safety Authority J. 13:3991.
Farber J.M., Gendel S.M., Tyler K.D., Boerlin P., Landry W.L., Fritschel S.C. \& Barrett T.J. 2001. Molecular typing and differentiation, p.127-156. In: Ibid. (Eds), Compendium of Methods for the Microbiological Examination of Foods. 4th ed. American Public Health Association, Washington, D.C. <http://dx.doi.org/10.2105/9780875531755ch11>.

Gill C.O. \& McGinnis J.C. 2003. Microbiological effects of hand washing at a beef carcass-breaking facility. J. Food Protect. 66(3):493-496. <http:// dx.doi.org/10.4315/0362-028X-66.3.493><PMid:12636307>

Gkana E., Lianou A. \& Nychas G.J. 2016. Transfer of Salmonella enterica Serovar Typhimurium from Beef to Tomato through Kitchen Equipment and the Efficacy of Intermediate Decontamination Procedures. J. Food Protect. 79(7):1252-1258. <http://dx.doi.org/10.4315/0362-028X.JFP15-531><PMid:27357047>

Hunter P.R. \& Gaston M.A. 1988. Numerical Index oh the discriminatory ability of typing systems: an application of Simpson's Index of Diversity. J. Clin. Microbiol. 26(11):2465-2466. <PMid:3069867>

Hur J., Jawale C. \& Lee J.H. 2012. Antimicrobial resistance of Salmonella isolated from food animals: a review. Food Res. Int. 45(2):819-830. <http:// dx.doi.org/10.1016/j.foodres.2011.05.014>

IAGRO 2018. Rebanho bovino de MS cresce, superando 21,8 milhões de cabeças. Agência Estadual de Defesa Sanitária Animal e Vegetal. Available at <http:// http://www.iagro.ms.gov.br/rebanho-bovino-de-ms-crescesuperando-218-milhoes-de-cabecas/> Accessed on Jun. 10, 2018.

Ibrahim W.A., Abd El-Ghany W.A., Nasef S.A. \& Hatem M.E. 2014. A comparative study on the use of real time polymerase chain reaction (RT-PCR) and standard isolation techniques for the detection of Salmonellae in broiler chicks. Int. J. Vet. Sci. Med. 2(1):67-71. <http://dx.doi.org/10.1016/j. ijvsm.2013.11.001>

ISO 2002. ISO 6579:2002: microbiology of food and animal feeding stuffs, horizontal method for the detection of Salmonella spp. International Organization for Standardization, Switzerland. 20p.

Jay J.M. 2000. Fresh meats and poultry, p.59-85. In: Jay J.M. (Ed.), Modern Food Microbiology. Aspen Publishers Inc., USA. <http://dx.doi.org/10.1007/9781-4615-4427-2_4>.

Lambert A.D., Smith J.P. \& Dodds K.L. 1991. Shelf life extension and microbiological safety of fresh meat: a review. Food Microbiol. 8(4):267297. <http://dx.doi.org/10.1016/S0740-0020(05)80002-4>

Madden R.H., Murray K.A. \& Gilmour A. 2004. Determination of the principal points of product contamination during beef carcass dressing processes in Northern Ireland. J. Food Protect. 67(7):1494-1496. <http://dx.doi. org/10.4315/0362-028X-67.7.1494><PMid:15270508>

Malorny B., Tassios P.T., Rådström P., Cook N., Wagner M. \& Hoorfar J. 2003. Standardization of diagnostic PCR for detection of foodborne pathogens. Int. J. Food Microbiol. 83(1):39-48. <http://dx.doi.org/10.1016/S01681605(02)00322-7><PMid:12672591>

Martínez-Chávez L., Cabrera-Diaz E., Pérez-Montaño J.A., Garay-Martínez L.E., Varela-Hernández J.J., Castillo A., Lucia L., Ávila-Novoa M.G., Cardona-López M.A., Gutiérrez-González P. \& Martínez-Gonzáles N.E. 2015. Quantitative distribution of Salmonella spp. and Escherichia coli on beef carcasses and raw beef at retail establishments. Int. J. Food Microbiol. 210(1):149-155. <http://dx.doi.org/10.1016/j.ijfoodmicro.2015.06.016><PMid:26125489>

Michener H.D. \& Elliott R.P. 1964. Minimum growth temperatures for foodpoisoning, fecal-indicator, and psychrophilic microorganisms. Adv. Food Res. 13:349-396. <http://dx.doi.org/10.1016/S0065-2628(08)60103-2> <PMid:14288887>

Myint M.S., Johnson Y.J., Tablante N.L. \& Heckert R.A. 2006. The effect of preenrichment protocol on the sensivity and specifity of PCR for detection of naturally contaminated Salmonella in raw poultry compared to conventional culture. Food Microbiol. 23(6):599-604. <http://dx.doi.org/10.1016/j. fm.2005.09.002><PMid:16943057> 
Olsen J.E., Brown D.J., Skov M.N. \& Christensen J.P. 1993. Bacterial typing methods suitable for epidemiological analysis applications in investigations of salmonellosis among livestock. Vet. Quartely 15(4):125-135. <PMid:8122347>

Oueslati W., Rjeibi M.R., Mhadhbi M., Jbeli M., Zrelli S. \& Ettriqui A. 2016. Prevalence, virulence and antibiotic susceptibility of Salmonella spp. strains, isolated from beef in Greater Tunis (Tunisia). Meat Sci. 119:154-159. <http://dx.doi.org/10.1016/j.meatsci.2016.04.037><PMid:27183540>

Papadopoulou O.S., Chorianopoulos N.G., Gkana E.N., Grounta A.V., Koutsoumanis K.P. \& Nychas G.J. 2012. Transfer of foodborne pathogenic bacteria to non-inoculated beef fillets through meat mincing machine. Meat Sci. 90(3):865-869. <http://dx.doi.org/10.1016/j.meatsci.2011.11.008> <PMid:22119672>

Penney N., Bigwood T., Barea H., Pulford D., LeROUX G.U.I.L.L., Cook R., Jarvis G. \& Brightwell G. 2007. Efficacy of a peroxyacetic acid formulation as an antimicrobial intervention to reduce levels of inoculated Escherichia coli 0157:H7 on external carcass surfaces on hot-boned beef and veal. J. Food Protect. 70(1):200-203.<http://dx.doi.org/10.4315/0362-028X-70.1.200> <PMid:17265881>

Perez-Rodriguez F., Castro R., Posada-Izquierdo G.D., Valero A., Carrasco E., García-Gimeno R.M. \& Zurera G. 2010. Evaluation of hygiene practices and microbiological quality of cooked meat products during slicing and handling at retail. Meat Sci. 86(2):479-485. <http://dx.doi.org/10.1016/j. meatsci.2010.05.038><PMid:20573456>

Podpečan B., Pengov A. \& Vadnjal S. 2007. The source of contamination of ground meat for production of meat products with bacteria Staphylococcus aureus. Slov. Vet. Res. 44(1/2):25-30.

Pordesimo L.O., Wilkerson E.G., Womac A.R. \& Cutter C.N. 2002. Process engineering variables in the spray washing of meat and produce. J. Food Protect. 65(1):222-237.<http://dx.doi.org/10.4315/0362-028X-65.1.222> $<$ PMid:11808801>

Prasai R.K., Phebus R.K., Zepeda C.M.G., Kastner C.L., Boyle A.E. \& Fung D.Y.C. 1995. Effectiveness of trimming and/or washing on microbiological quality of beef carcasses. J. Food Protect. 58(10):1114-1117. <http://dx.doi. org/10.4315/0362-028X-58.10.1114>

Rahkio M. \& Korkeala H. 1996. Microbiological contamination of carcasses related to hygiene practice and facilities on slaughtering lines. Acta Vet. Scand. 37(3):219-228. <PMid:8996868>

Rall V.L.M., Rall R., Aragon L.C. \& Silva M.G. 2005. Evaluation of three enrichment broths and five plating media for Salmonella detection in poultry. Braz. J. Microbiol. 36(2):147-150. <http://dx.doi.org/10.1590/ S1517-83822005000200009>

RASFF 2018. Notifications by product category and notifying country. Rapid Alert System for Food and Feed, European Commission. Available at <https:// webgate.ec.europa.eu/rasff-window/portal/?event=searchResultList> Accessed on Mar. 2, 2018.
Raufu I.A., Lawan F.A., Bello H.S., Musa A.S., Ameh J.A. \& Ambali A.G. 2014. Occurrence and antimicrobial susceptibility profiles of Salmonella serovars from fish in Maiduguri, sub-Saharah, Nigeria. Egypt. J. Aquat. Res. 40(1):5963. <http://dx.doi.org/10.1016/j.ejar.2014.01.003>

Rhoades J.R., Duffy G. \& Koutsoumanis K. 2009. Prevalence and concentration of verocytotoxigenic Escherichia coli, Salmonella enterica and Listeria monocytogenes in the beef production chain: a review. Food Microbiol. 26(4):357-376. <http://dx.doi.org/10.1016/j.fm.2008.10.012> $<$ PMid:19376457>

Ribot E.M., Fair M.A., Gautom R., Cameron D.N., Hunter S.B., Swaminathan B. \& Barrett T.J. 2006. Standardization of Pulsed-Field Gel Electrophoresis Protocols for the Subtyping of Escherichia coli 0157:H7, Salmonella, and Shigella for PulseNet. Foodborne Pathog. Dis. 3(1):59-67. <http://dx.doi. org/10.1089/fpd.2006.3.59><PMid:16602980>

Sans P. \& Combris P. 2015. World meat consumption patterns: An overview of the last fifty years (1961-2011). Meat Sci. 109:106-111. <http://dx.doi. org/10.1016/j.meatsci.2015.05.012 > <PMid:26117396>

Settanni L. \& Corsetti A. 2007. The use of multiplex PCR to detect and differentiate food and beverage-associated microorganisms: a review. J. Microbiol. Methods 69(1):1-22. <http://dx.doi.org/10.1016/j.mimet.2006.12.008> $<$ PMid:17280731>

Silley P. 2012. Susceptibility testing methods, resistance and breakpoints: what do these terms really mean? Rev. Sci. Tech. OIE 31(1):33-41. <http:// dx.doi.org/10.20506/rst.31.1.2097> <PMid:22849266>

Skyberg J.A., Logue C.M. \& Nolan L.K. 2006. Virulence Genotyping of Salmonella spp. with Multiplex PCR. Avian Dis. 50(1):77-81. <http:// dx.doi.org/10.1637/7417.1><PMid:16617986>

Van Boxstael S., Dierick K., Van Huffel X., Uyttendaele M., Berkvens D., Herman L., Bertrand S., Wildemauwe C., Catry B., Butaye P. \& Imberechts H. 2012. Comparison of antimicrobial resistance patterns and phage types of Salmonella Typhimurium isolated from pigs, pork and human in Belgium between 2001 and 2006. Food Res. Int. 45(2):913-918. <http://dx.doi org/10.1016/j.foodres.2011.05.025>

WHO 2005. Drug-resistant Salmonella. Fact sheet n. 139, Food Safety Department, Word Health Organization. Available at <http://www.who. int/mediacentre/factsheets/fs139/en/> Accessed on Jun. 17, 2016.

Wilhelm B., Rajić A., Greig J.D., Waddell L. \& Harris J. 2011. The effect of hazard analysis critical control point programs on microbial contamination of carcasses in abattoirs: a systematic review of published data. Foodborne Pathog. Dis. 8(9):949-960. <http://dx.doi.org/10.1089/fpd.2010.0809> $<$ PMid:21568689>

Wilson I.G. 1997. Inhibition and facilitation of nucleic acid amplification. Appl. Environ. Microbiol. 63(10):3741-3751. <PMid:9327537> 